\title{
Sosialisasi Bahaya Narkotika Sebagai Bentuk Kenakalam Remaja Dikalangan Siswa Madrasah Tsanawiyah Kabupaten Sorong
}

\author{
Uswatul Mardliyah $^{1}$, Mira Herawati Soekamto ${ }^{2}$ \\ 1,2 Universitas Muhammadiyah sorong, Indonesia \\ Email: uswatul.mardliyah@gmail.com
}

\begin{abstract}
ABSTRAK
Kenakalan remaja dan bahaya narkotika di kalangan siswa sekolah menengah atas memang perlu mendapatkan perhatian yang serius. Sebagai generasi yang meneruskan cita-cita bangsa sudah sepatutnya mereka dibekali dengan moralitas yang baik. Adanya berbagai macam factor yang menyebabkan mereka terjerumus pada hal-hal yang menyimpang tersebut tentu meresahkan banyak orang tua dan juga masyarakat secara umum. Peran pendidika, agama, keluarga disini tentu sangat penting guna memberikan pemahaman terhadap remaja terhadap dampak-dampak yang dihasilkan dari perilaku melanggar ataupun menyimpang yang dilakukan oleh kaum remaja. Dengan mengadakan sosialisasi di sekolah diharapkan remaja dapat membuka wawasan berpikir dan mencermati makna kenakalan remaja dan bahaya narkotika, sehingga mereka bias lebih berhati-hati dalam bergaul dalam lingkungan masyarakat.
\end{abstract}

Kata kunci: Bahaya, Narkotika, Kenakalan, Remaja

\section{Dissemination of the Dangers of Narcotics as a Form of Adolescent Delinquency Among Students at Madrasah Tsanawiyah (MTS) Sorong Regency}

\begin{abstract}
Juvenile delinquency and the dangers of narcotics among high school students need serious attention. As a generation that continues the ideals of the nation, they should be equipped with good morality. The existence of various kinds of factors that cause them to fall into these deviant things is certainly troubling for many parents and also society in general. The role of education, religion, and family here is of course very important in order to provide an understanding of adolescents on the effects resulting from violating or deviant behavior by adolescents. By holding outreach at school, it is hoped that adolescents can open their minds and examine the meaning of juvenile delinquency and the dangers of narcotics, so that they can be more careful in associating with the community.
\end{abstract}

Keywords: Danger, Narcotics, Delinquency, Adolescents

\section{PENDAHULUAN}

Remaja merupakan masa yang rentan bagi seseorang untuk menentukan langkah-langkah kedepan, dalam hal ini remaja.Remaja tentu masih sangat mudah terpengaruh dengan segala macam situasi yang terjadi di sekitar lingkungan.Remaja adalah masa peralihan dari kanak-kanak ke dewasa. Seorang remaja sudah tidak lagi dapat dikatakan sebagai kanakkanak, namun ia masih belum cukup matang untuk dapat dikatakan dewasa. Remaja juga merupakan aset masa depan suatu bangsa. Di samping hal-hal yang menggembirakan dengan kegiatan remaja-remaja pada waktu yang akhir-akhir ini dan pembinaan yang dilakukan oleh organisasi-organisasi pelajar dan mahasiswa, kita melihat pula arus kemorosotan moral yang semakin melanda di kalangan sebagian pemuda-pemuda kita, yang lebih terkenal dengan sebutan kenakalan remaja. Dalam 
surat kabar-surat kabar sering kali kita membaca berita tentang perkelahian pelajar, penyebaran narkotika, pemakaian obat bius, minuman keras, penjambret yang dilakukan oleh anak-anak yang berusia belasan tahun, meningkatnya kasus-kasus kehamilan di kalangan remaja putri dan lain sebagainya.

Becker (dalam Soerjono Soekanto, 1998), menyatakan bahwa pada dasarnya setiap manusia memiliki dorongan untuk melanggar aturan pada situasi tertentu.Tetapi pada kebanyakan orang dorongan-dorongan tersebut biasanya tidak menjadi kenyataan yang berwujud penyimpangan. Hal tersebut karena orang normal biasanya dapat menahan diri dari dorongan dorongan untuk berperilaku menyimpang.Kemampuan menahan diri inilah yang seharusnya dipelajari individu selama masa remaja.

Kenakalan remaja dan bahaya narkotika dikalangan anak sekolah menengah ini menjadi fenomena social yang harus segera dapat diatasi bersama.Kenakalan remaja yang sering terjadi dewasa ini tampaknya sudah kehilangan ciri nakalnya dan sudah menjurus pada tindakan kriminal yang dapat membahayakan keselamatan dan ketenteraman hidup masyarakat.Salah satu bentuk kenakalan remaja adalah keterlibatan remaja dalam melakukan tindak pidana penyalahgunaan narkoba.Masalah penyalahgunaan narkoba mempunyai dimensi yang luas dan kompleks, baik dari sudut medik, psikiatri, kesehatan jiwa, maupun psikososial. Pengguna narkoba dapat merusak tatanan kehidupan keluarga, lingkungan masyarakat dan lingkungan sekolahnya, bahkan langsung atau tidak langsung merupakan ancaman bagi kelangsungan pembangunan serta masa depan bangsa dan negara Indonesia.

Sebagai generasi penerus cita-cita bangsa maka sudah seharusnya menjadi tugas bersama sebagai upaya untuk menyelesaikan persoalan-persoalan kenalakan remaja dan bahaya narkotika di kalangan sekolah menengah atas khususnya di distrik aimas kabupaten sorong tersebut dan menjaga generasi remaja agar tidak terjerumus kedalam bahaya narkotika yang dapat menyesatkan pola pikir dan menghalalkan segala cara untuk memenuhi keinginan terhadap perilaku menyimpang dan penyalahgunaan narkotika.

\section{METODE PELAKSANAAN}

Tempat dilaksanakan kegiatan pengabdian ini adalah di Madrasah Tsanawiyah (MTS) di Aimas Kabupaten Sorong. Untuk kegiatan ini metode yang digunakanadalah dengan teknik informasi komunikatif yang menggunakan 2 pendekatan yaitu :

Ceramah atau Penyampaian Materi yakni kegiatan yang dilakukan secara langsung/ tatap mukadihadapan para pelajar/ siswa siswi sekolah Madrasah Tsanawiyah (MTS )di Kelurahan Aimas tentang pengertian kenakalan remaja, bahaya narkotika, dampak penggunaan, serta bagaimana mengatasi kenakalan remaja dan mengatasi bahaya narkotika di lingkungan remaja.

Diskusi dan Tanya jawab ; yakni setelah pemaparan materi maka dubuatlah sesi Tanya jawab lyang bertujuan untuk memecahkan suatu masalah guna mencapai tujuan tertentu. Dalam kegiatan ini diharapkan adanya timbal-balik dari siswa/siswi pelajar untuk menerapkan cara mengatasi kenakalan remaja dan bahaya narkotika yang diajarkan dalam proses memperbaiki dan menjaga generasi muda yang bermutu, berkualitas dan bermoral.

\section{HASIL PELAKSANAAN KEGIATAN}

Dari hasil kegiatan pelaksanaan sosialisasi bahaya narkotika sebagai bentuk kenakalan remaja yang diikuti oleh siswa sekolah menengah pertama (MTS) kelurahan Aimas, kabupaten Sorong menunjukkan bahwa setiap siswa/siswi mempunyai tingkat pengetahuan atau wawasan 
tentang kenakalan remaja yang berbeda-beda terutama terhadap dampak yang ditimbulkan dikemudian hari.

Materi yang diberikan terbagi menjadi 3 gambaran penting yaitu menyangkut pengertian dari kenakalan remaja, bentuk-bentuk kenakalan remaja dan dampak dari kenakalan remaja baik di masa sekarang ataupun di masa akan datang.

Dalam pemberian materi tentang kenakalan remaja yang lebih difokuskan tentang bahaya penggunaan narkotika dijelaskan oleh pemateri mulai dari uraian pendahuluan tentang pengertian kenakalan remaja, bentuk-bentuk kenalakan remaja dan yang paling sering dialami sekarang ini adalah penggunaan narkotika di kalangan remaja, kasus-kasus penggunaan narkoba yang terjadi di kalangan siswa dan dampak dari penggunaan tersebut.

Seperti kita ketahui narkotika merupakan obat-obatan terlarang yang mempunyai dampak negative bagi penggunaannnya dan masa remaja merupakan masa dimana anak-anak berusaha mencari jati dirinya sehingga dikatakan sebagai masa transisi (Amanda et al, 2017). Pada masa ini biasanya anak-anak cenderung mengalami krisis kepercayaan sehingga bentuk pelampiasan kepuasan diri akan mengarah pada kenakalan remaja yang salah satunya adalah penggunaan narkoba.

Efek dari penggunaan narkoba jelas mempunyai dampak negatif yang akan menyebabkan gangguan mental dan perilaku. Dampak lebih lanjut mengkibatkan terganggunya sistem neuro-transmitter pada susunan saraf pusat di otak. Jika ini terjadi pada remaja sebagai penerus bangsa maka tentu saja masa depan negara juga akan hancur.

Menurut paparan dari pemateri narkoba mempunyai 3 efek penting yaitu :

1. Depresan, yaitu menekan sistem sistem syaraf pusat dan mengurangi aktifitas fungsional tubuh sehingga pemakai merasa tenang, bahkan bisa membuat pemakai tidur dan tak sadarkan diri. Bila kelebihan dosis bisa mengakibatkan kematian. Jenis narkoba depresan antara lain opioda, dan berbagai turunannya seperti morphin dan heroin.Contoh yang populer sekarang adalah Putaw.

2. Stimulan, merangsang fungsi tubuh dan meningkatkan kegairahan serta kesadaran. Jenis stimulan: Kafein, Kokain, Amphetamin. Contoh yang sekarang sering dipakai adalah Shabushabu dan Ekstasi.

3. Halusinogen, efek utamanya adalah mengubah daya persepsi atau mengakibatkan halusinasi. Halusinogen kebanyakan berasal dari tanaman seperti mes caline dari kaktus dan psilocybin dari jamur-jamuran. Selain itu ada jugayang diramu di laboratorium seperti LSD. Yang paling banyak dipakai adalah marijuana atau ganja.

Sedangkan langkah-langkah yang dapat dilakukan untuk mencegah dan menanggulangi kenakalan remaja dari bahaya narkotika dapat dilakukan dengan beberapa langkah antara lain :

1. Melalui pendekatan keluarga/orang tua karena orang tua adalah bagian yang terdekat dengan putra-putri sehingga figure yang untuk panutan atau teladan yang dihormati.

2. Melalui pendekatan pendidikan. Pengetahuan atau wawasan ttentang bahaya narkotika sangat penting dipelajari oleh setiap anak di bangku pendidikan agar pemahaman tentang bahaya narkotika tersebut dapat dihindari.

3. Pendekatan Hukum, Penegakan hukum terhadap para pelaku tindak pidana narkoba dengan modus operandi mempergunakan teknologi canggih harus diantisipasi dengan peningkatan kualitas penegak hukum dan kelengkapan perangkat hukum serta tatanan hukum yang dapat melindungi kepentingan masyarakat

Siswa peserta yang mengikuti kegiatan sosialisasi inipun juga cukup senang dan antusias dengan kegiatan tersebut, dan hal ini dibuktikan dengan adanya sesi Tanya jawab dimana pelajar 
ini mulai aktif dalam hal bertanya. Remaja ini banyak sekali rasa ingin tahunya dalam hal dampak-dampak dari penggunaan narkotika, sehingga memang membuka wawasan dalam menanggapi kenakalan dan bahaya narkotika ini khususnya mereka selaku remaja. Masa depan yang cerah tentu selalu jadi impian setiap remaja pada umumnya sehingga pembekalan ini diharapkan memberikan kesadaran dalam menentukan pergaulan sehingga tidak terjerumus.

Pada tahapan kegiatan sosialisasi ini juga dilakukan evaluasi kepada siswa/siswi sebagai bentuk dari keberhasilan capaian dari kegiatan ini. Evaluasi ini dilakukan dalam bentuk menjawab pertanyaan menyangkut materi sosialisasi.

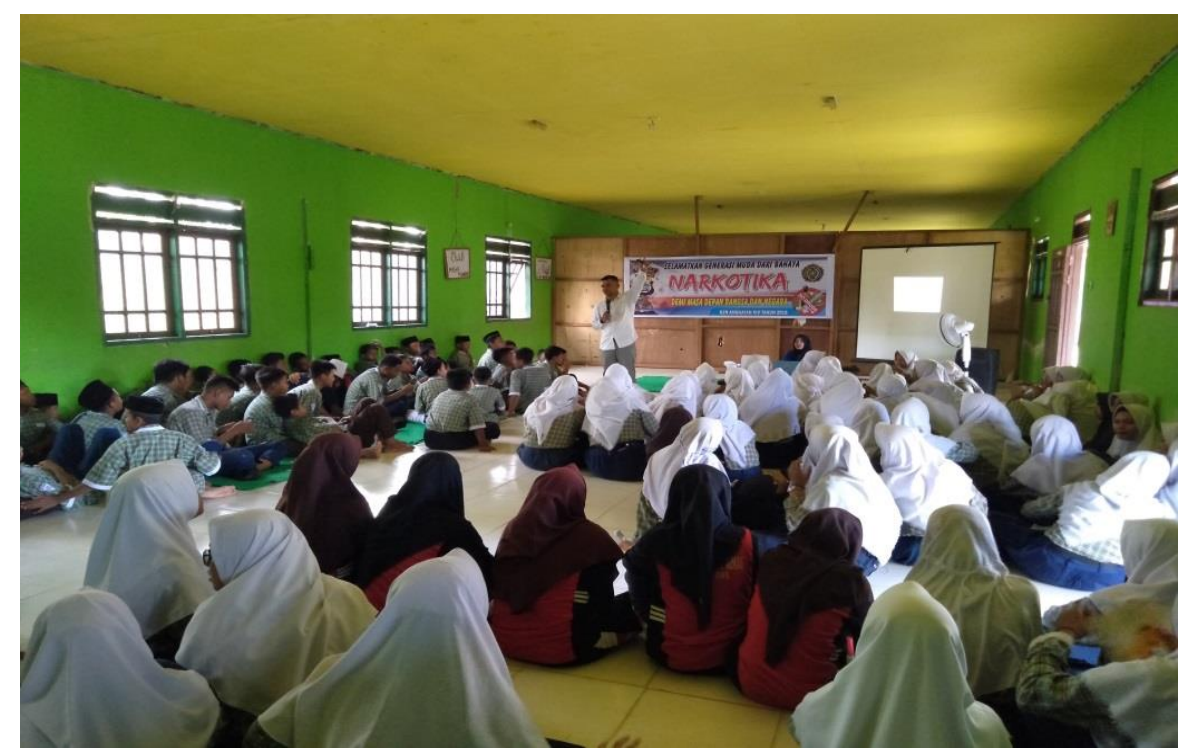

Gambar 1. Proses kegiatan sosialisasi

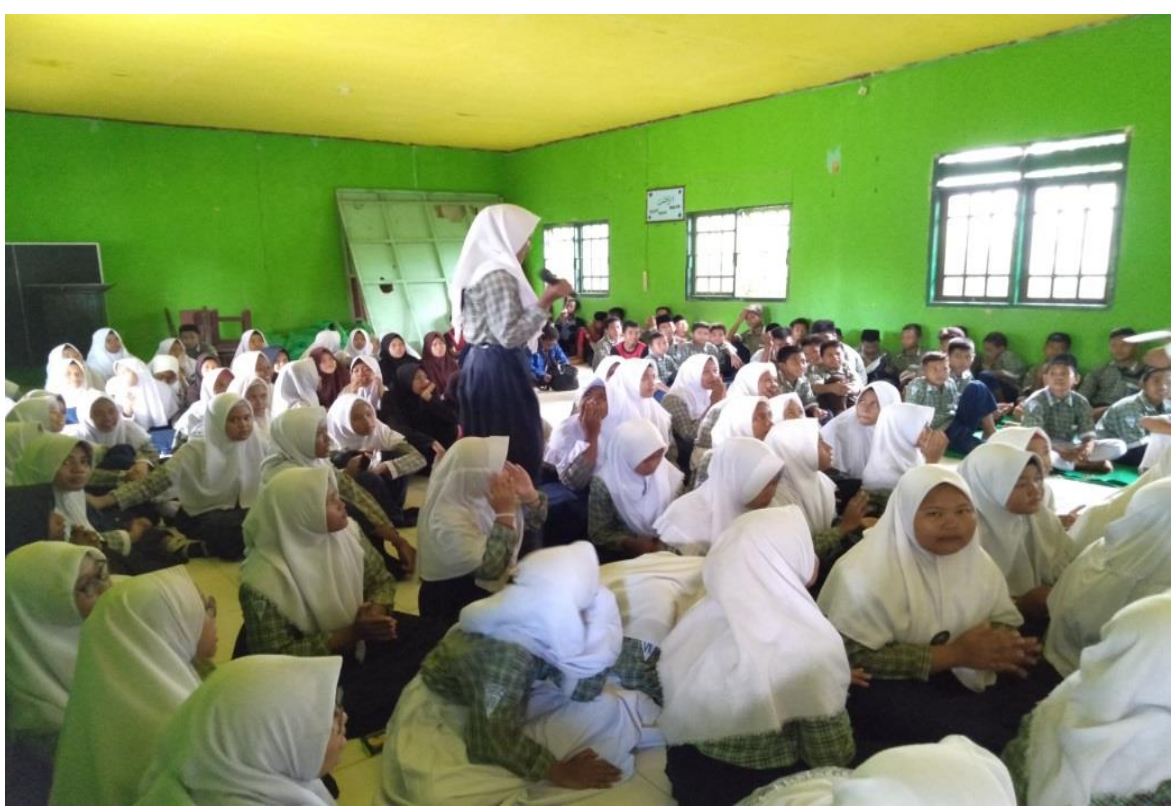

Gambar 2. Proses Tanya Jawab Peserta Kegiatan Sosialisasi

Hasil evaluasi kegiatan menunjukkan bahwa setiap pemberian materi mendapatkan respon yang sangat baik. Hal ini ditunjukkan dari hasil umpan balik materi yang dilakukan sebelum dan setelah 
pemberian materi menunjukkan adanya peningkatan pengetahuan tentang kegiatan sosialisasi ini. Hasil evaluasi peningkatan pemahaman siswa dapat di lihat dari tabel 1.

Tabel 1. Evaluasi hasil umpan balik pemahaman siswa tentang Bahaya narkotika Dikalangan siswa Madrasah Tsanawiyah (MTS) Kabupaten sorong

\begin{tabular}{llcc}
\hline \multirow{2}{*}{ No. } & \multicolumn{2}{c}{ Uraian Pertanyaan } & \multicolumn{2}{c}{ \% Ketepatan Menjawab } \\
\cline { 3 - 4 } & & Sebelum Materi & Sesudah \\
\hline 1. & Pengertian Kenakalan remaja & 40 & 95 \\
2. & Macam-macam Kenakalan remaja & 30 & 90 \\
3. & Bahaya penggunaan Narkona & 27 & 91 \\
4. & Dampak Penggunaan Narkoba & 25 & 94 \\
\hline & Rata-rata ketepatan menjawab & 30.5 & 92.5 \\
\hline
\end{tabular}

Sumber Data diolah, 2020

Tabel 1 menunjukkan tingkat pemahaman siswa masih sangat rendah terhadap bahaya narkotika yang merupakan bagian dari kenakalan siswa. Hal ditunjukkan dari hasil evaluasi awal kegiatan dengan rata-rata persentase menjawab masih sangat rendah yaitu sebesar 30.5\%, namun setelah diberikan materi dalam kegiatan sosialisasi ini maka terjadi peningkatan dengan rata-rata persentase sebesar $92.5 \%$ dari semua pertanyaan.

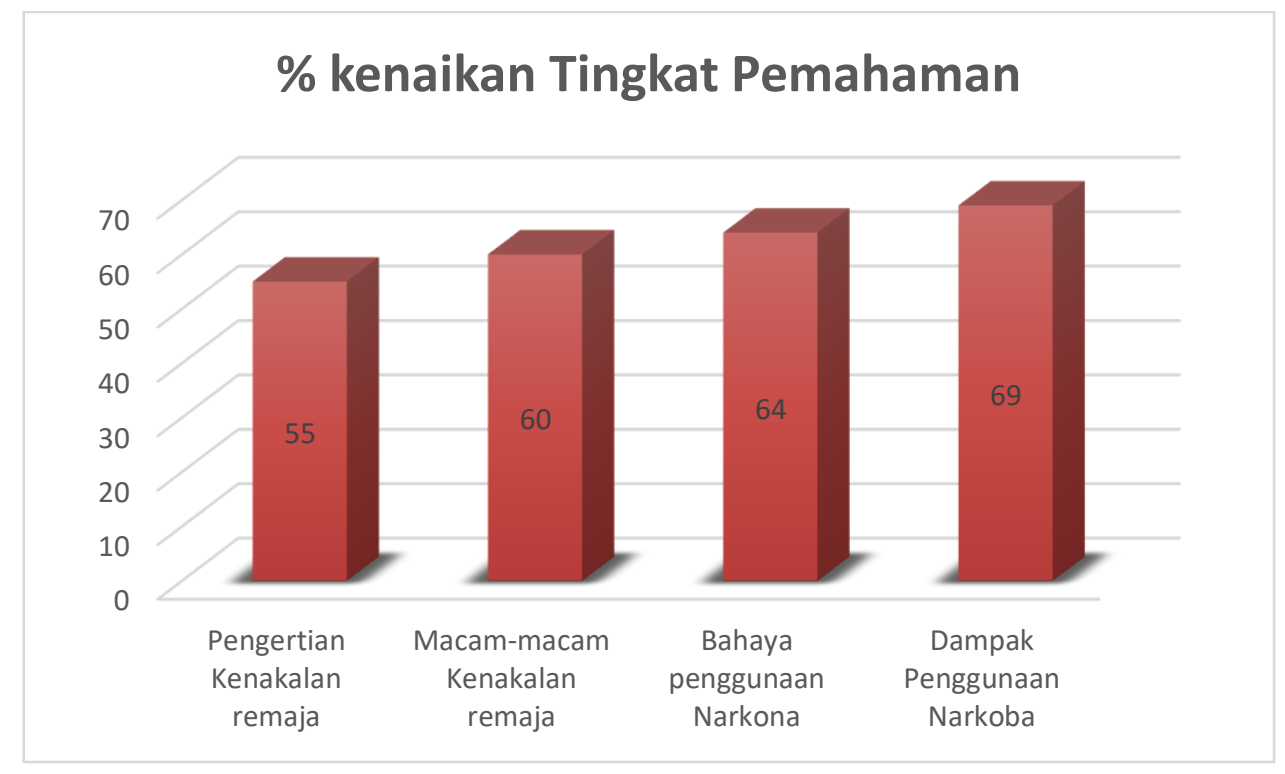

Gambar 3. Grafik Persentasi Kenaikan Tingkat Pemahaman Siswa/Siswi Mts Kabupaten Sorong.

Dari tabel 1 dan gambar 3, menunjukkan bahwa setiap poin pertanyaan mempunyai perubahan pada peningkatan pemahaman siswa/siswi tentang kenakalan remaja dan bahaya narrkotika. Dari mulai pengertian kenakalan remaja mengalami peningkatan sebesar $55 \%$, macam-macam kenakalan remaja sebesar $60 \%$, bahaya penggunaan narkotika sebesar $64 \%$ dan dampak penggunaan narkotika sebesar $69 \%$. Hal ini menunjukkan bahwa dari kegiatan ini mempunyai dampak positif dari adanya peningkatan wawasan siswa terhadapa bahaya narkotika sebagai bentuk kenakalam remaja yang saat ini sangat sering dilakukan.

\section{KESIMPULAN}


Dari hasil kegiatan sosialiasi bahaya narkotika sebagai bentuk kenakalam remaja dikalangan siswa Madrasah Tsanawiyah (MTS) Kabupaten Sorong dapat disimpulkan bahwa :

1. Pengetahuan siswa/siswi masih sangat rendah yang ditunjukan rata-rata dari hasil evaluasi awal sebesar $30.5 \%$,

2. Hasil evaluasi setelah pemberian materi menunjukan adanya peningkatan pengetahuan siswa/siswi tentang kenakalan remaja dan bahaya narkotika dengan rata-rata persentase sebesar $92,5 \%$.

3. Rata-rata peningkatan tersebut berada pada persentase diatas $50 \%$ kenaikan tingkat pemahaman siswa/siswi.

\section{DAFTAR PUSTAKA}

Amanda, Maudy Pritha, Sahadi Humaedi, and Meilanny Budiarti Santoso. "Penyalahgunaan Narkoba Di Kalangan Remaja (Adolescent Substance Abuse)." Prosiding Penelitian dan Pengabdian kepada Masyarakat 4.2 (2017).

Eleanora, F. N. (2021). Bahaya Penyalahgunaan Narkoba Serta Usaha Pencegahan Dan Penanggulangannya (Suatu Tinjauan Teoritis). Jurnal hukum, 25(1), 439-452.

Mannuhung, Suparman. "Penanggulangan Tingkat Kenakalan Remaja Dengan Bimbingan Agama Islam." To Maega| Jurnal Pengabdian Masyarakat 2.1 (2019): 9-16.

Syafii, A. (2009). Pengaruh Narkoba Terhadap Kenakalan Remaja di Sulawesi Tengah. Media Litbang Sulteng, 2(2).

Sumara, Dadan Sumara, Sahadi Humaedi, and Meilanny Budiarti Santoso. "Kenakalan remaja dan penanganannya." Prosiding Penelitian dan Pengabdian 